\title{
PENINGKATAN HASIL BELAJAR PESERTA DIDIK DALAM PEMBELAJARAN EKONOMI MENGGUNAKAN METODE CERAMAH DAN DISKUSI KELOMPOK PADA SMA NEGERI 1 KATINGAN HILIR
}

\author{
Oleh \\ Erni Berliana,* Iin Nurbudiyani** \\ Email: iinnurbudiyani@gmaial.com
}

\begin{abstract}
This study aims to determine the learning activities of students and find out the improvement in student learning outcomes. The type of this research is Classroom Action Research (CAR) with research subjects of all students of class X-7 of SMAN 1 Katingan Hilir, amounting to 24 students. Data collection techniques in this study used tests and observations. Data analysis uses qualitative and quantitative data analysis. The results of this study indicate that: (1) the use of lecture methods and group discussions on economic subjects are more active students which are shown by the acquisition of scores above 3, (2) the use of lecture methods and group discussions on economic subjects can improve learning outcomes students shown by obtaining an average score of 61.25 in the first cycle increased to 80 in the second cycle. Classical learning completeness also increased with a value of $50 \%$ in the first cycle increased to $87.5 \%$ in the second cycle.
\end{abstract}

(C) Muhammadiyah University Palangkaraya

Keywords: Economic Learning Outcomes, Lecture Methods and Group Discussions

\begin{abstract}
ABSTRAK
Penelitian ini bertujuan untuk mengetahui aktivitas belajar peserta didik dan mengetahui peningkatan hasil belajar peserta didik. Jenis penelitian ini adalah Penelitian Tindakan Kelas (PTK) dengan subjek penelitian seluruh peserta didik kelas X-7 SMAN 1 Katingan Hilir yang berjumlah 24 orang peserta didik. Teknik pengumpulan data dalam penelitian ini menggunakan tes dan observasi. Analisis data menggunakan analisis data kualitatif dan kuantitatif. Hasil penelitian ini menunjukan bahwa: (1) penggunaan metode ceramah dan diskusi kelompok pada mata pelajaran ekonomi lebih aktif peserta didik yang ditunjukan dengan perolehan skor hasil pengamatan diatas 3, (2) penggunaan metode ceramah dan diskusi kelompok pada mata pelajaran ekonomi dapat meningkatkan hasil belajar peserta didik yang ditunjukan dengan perolehan nilai rata-rata 61,25 pada siklus I meningkat menjadi 80 pada siklus II. Ketuntasan belajar secara klasikal juga mengalami peningkatan dengan nilai $50 \%$ pada siklus I meningkat menjadi $87,5 \%$ pada siklus II.
\end{abstract}

(C) Universitas Muhammadiyah Palangkaraya

Kata Kunci: Hasil Belajar Ekonomi, Metode Ceramah dan Diskusi Kelompok

Erni Berliana* Mahasiswa FKIP UM Palangkaaraya

Iin Nurbudiyani** Dosen Universitas Muhammadiyah Palangkaraya 


\section{PENDAHULUAN}

Kemampuan pembelajar juga menjadi faktor penting dalam mempengaruhi proses belajar mengajar, seperti dapat dipahami bahwa setiap manusia mempunyai kemampuan yang berbeda-beda. Karena itu, seseorang yang memiliki kemampuan dibidang tertentu belum tentu memiliki kemampuan dibidang lainnya.

Kemampuan pembelajar juga demikian kolerasinya dengan motivasi akan terlihat ketika pembelajar mengetahui bahwa kemampuannya ada pada bidang tertentu, sehingga ia akan termotivasi dengan kuat untuk terus menguasai dan mengembangkan kemampuannya dibidang tersebut.

Untuk melihat suatu keberhasilan proses pendidikan dapat dilihat dari hasil belajar peserta didik dan dari aktivitas belajar peserta didik itu sendiri. Belajar dapat juga dikatakan sebagai salah satu proses yang dimulai dengan adanya dorongan, semangat dan upaya yang timbul dalam diri seseorang sehingga orang itu melakukan kegiatan belajar.

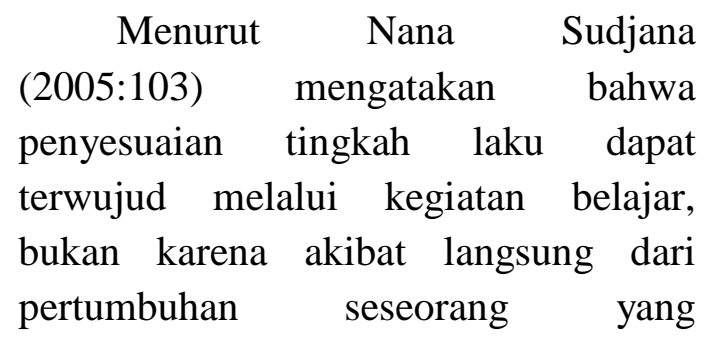
melakukan kegiatan belajar. Kegiatan belajar itu memiliki unsur-unsur tersendiri yang dapat membedakan antara kegiatan belajar dan bukan belajar karena unsur tersebut harus mencangkup tujuan dari belajar itu sendiri.
Dalam penelitian ini peneliti mengidentifikasi dan menemukan sebuah fenomena pada saat penulis melakukan observasi di sekolah SMAN 1 Katingan Hilir, penulis menemukan suatu permasalahan dengan metode pembelajaran yang guru-guru gunakan pada saat proses belajar mengajar yang terlihat sangat kaku, monoton terlalu konvensional dan belum ditemukannya metode pembelajaran yang tepat karena hal itu yang dapat menyebabkan kemampuan peserta didik itu menurun. Menurut Nana Sudjana (2007:112) mengatakan bahwa hasil belajar adalah suatu akibat dari proses belajar dengan menggunakan alat pengukuran yaitu berupa tes yang disusun secara terencana baik tes tertulis, tes lisan maupun tes perbuatan. Untuk melihat hasil belajar dilakukan suatu penilaian terhadap peserta didik yang bertujuan untuk mengetahui apakah peserta didik telah menguasai suatu materi atau belum. Sedangkan menurut Dimyanti dan Mudjiono (2006:3-4) juga menyebutkan hasil belajar merupakan hasil dari suatu interaksi tindak belajar dan tindak mengajar yang dapat dilihat dari dua sisi yaitu pertama, dari sisi guru tindak mengajar diakhiri dengan proses evaluasi hasil belajar. Kedua, dari sisi peserta didik hasil belajar merupakan pengajaran dari puncak proses belajar.

Menurut Kunandar (2008:277) mengemukakan bahwa aktivitas belajar peserta didik adalah keterlibatan peserta didik dalam bentuk sikap, pikiran, dan aktivitas dalam kegiatan pembelajaran guna menunjang keberhasilan proses belajar mengajar dan memperoleh 
manfaat dari kegiatan tersebut. Peningkatan aktivitas peserta didik yaitu meningkatnya jumlah siswa yang terlibat aktif belajar, meningkatnya jumlah peserta didik yang bertanya dan menjawab, meningkatnya jumlah peserta didik yang saling berinteraksi membahas materi pembelajaran.

Menurut A. Sabri (2007:200) Mengatakan bahwa dengan alasan karena diskusi merupakan metode yang sulit dipr ediksi hasilnya karena interaksi antar peserta didik muncul secara spontan sehingga hasil dan arah diskusi sulit ditentukan dan sering juga guru mengganggap bahwa metode pembelajaran diskusi biasanya memerlukan waktu yang cukup panjang padahal waktu pembelajaran di dalam kelas sangat terbatas sehingga keterbatasan itu tidak mungkin dapat menghasilkan sesuatu secara tuntas.

Dengan menggunakan metode ceramah dan diskusi kelompok peneliti dapat mengetahui sampai mana masalah yang ada dapat terpecahkan karena rendahnya hasil belajar peserta didik dan rendahnya aktivitas peserta didik untuk mata pelajaran ekonomi. Kemampuan peserta didik berpikir kritis pada mata pelajaran ekonomi tersebut yang dapat mendorong peserta didik agar lebih maju dan aktif dalam berpikir dan bertindak. Dan pembelajaran ini juga dapat membuat peserta didik lebih aktif di kelas untuk menemukan sesuatu yang baru untuk dipelajari sehingga disaat guru memberikan suatu permasalahan yang harus dipecahkan maka guru dapat sangat berperan penting dan aktif.
Menurut Djamarah (2008:10) mengatakan bahwa metode ceramah adalah cara penyajian pelajaran yang dilakukan oleh guru dengan penuturan atau penjelasan lisan secara langsung terhadap peserta didik (Metode ini tidaklah selalu jelek dalam penggunaannya, asalkan dalam menggunakan metode ini betul- betul disiapkan dengan baik, didukung dengan alat dan media serta memperhatikan batas-batas kemungkinan dalam penggunaannya. Sedangkan menurut (Killen 2007: 11) mengatakan bahwa metode ceramah merupakan metode yang sampai saat ini sering digunakan oleh setiap guru atau instruktur. Guru biasanya belum merasa puas jika dalam proses pembelajaran tidak melakukan ceramah, demikian juga dengan peserta didik mereka akan belajar jika ada guru yang memberikan materi pelajaran melalui ceramah sehingga timbul persepsi jika ada guru yang berceramah maka ada proses belajar.

Dari pendapat tersebut di atas dapat disimpulkan bahwa metode ceramah merupakan metode yang sering kali dianggap sebagai metode yang membosankan karena metode ceramah lebih dominan dengan menjelaskan.

Diskusi adalah metode pembelajaran yang menghadapkan peserta didik pada suatu permasalahan, selama ini banyak guru yang merasa keberatan untuk menggunakan metode diskusi dalam proses pembelajaran. Menurut A. Sabri (2007:200) Mengatakan bahwa dengan alasan karena diskusi merupakan metode yang sulit dipr ediksi hasilnya karena 
interaksi antar peserta didik muncul secara spontan sehingga hasil dan arah diskusi sulit ditentukan dan sering juga guru mengganggap bahwa metode pembelajaran diskusi biasanya memerlukan waktu yang cukup panjang padahal waktu pembelajaran di dalam kelas sangat terbatas sehingga keterbatasan itu tidak mungkin dapat menghasilkan sesuatu secara tuntas. Sebenarnya hal ini tidak perlu dirisaukan oleh para guru karena dengan perencanaan dan persiapan yang matang kejadian semacam itu tidak akan terjadi dan dapat dihindari.Selain itu menurut Killen (2007:22) mengatakan bahwa diskusi kelompok dinamakan juga diskusi kelas, pada diskusi ini permasalahan yang disajikan oleh guru dipecahkan oleh kelas secara keseluruhan. Pengatur jalannya diskusi adalah guru, lain halnya dengan diskusi kelompok kecil. Pada diskusi kelompok ini peserta didik dibagi dalam beberapa kelompok, setiap kelompok terdiri dari 3-7 orang. Proses pelaksanaan diskusi ini dimulai dari guru menyajikan masalah dengan beberapa sub-masalah yang dipecahkan setiap kelompok dan diakhiri dengan laporan setiap kelompok.

Tujuan utama metode ini adalah untuk memecahkan suatu permasalahan, menjawab pertanyaan, menambah dan memahami pengetahuan peserta didik serta membuat suatu keputusan oleh karena itu, diskusi bukanlah debat yang bersifat adu argumentasi. Diskusi lebih bersifat bertukar pengalaman untuk menentukan keputusan secara bersamasama.
Secara umum ada dua jenis diskusi yang biasa dilakukan dalam proses pembelajaran yaitu diskusi kelompok dan diskusi kelompok kecil. Jadi, dapat disimpulkan diskusi kelompok merupakan diskusi yang dilakukan secara berkelompok besar maupun kecil dengan tujuan untuk memecahkan permasalahan secara kelompok.

Berdasarkan paparan di atas tujuan penelitian ini adalah:

1. Untuk mengetahui aktivitas belajar peserta didik dalam proses pembelajaran ekonomi dengan menerapkan metode ceramah dan diskusi kelompok.

2. Untuk mengetahui peningkatan hasil belajar ekonomi peserta didik dengan menerapkan metode ceramah dan diskusi kelompok di SMA Negeri 1 Katingan Hilir. Peneliti tertarik mengadakan penelitian dan mengajukan judul penelitian yang berjudul "Peningkatan Hasil Belajar Peserta Didik Dalam Pembelajaran Ekonomi Menggunakan Metode Ceramah dan Diskusi Kelompok pada Kelas X-7 SMA Negeri 1 Katingan Hilir“.

\section{METODE PENELITIAN}

Penelitian menggunakan Penelitian Tindakan Kelas (PTK) yang dilakukan oleh peneliti secara langsung. Peneliti disini bertindak secara langsung dalam melakukan penelitian sejak awal sampai akhir penelitian yaitu berupa laporan.

Dalam penelitian ini, peneliti bertindak sebagai peneliti dan pengajar. Tujuan utama dari penelitian tindakan 
kelas ini adalah untuk meningkatkan hasil belajar dan aktivitas belajar peserta didik itu sendiri dimana guru merupakan pelengkap yang secara penuh terlibat dalam penelitian.

\section{HASIL DAN PEMBAHASAN}

1. Hasil pengamatan aktivitas guru dan peserta didik

Hasil pengamatan terhadap aktivitas guru dan peserta didik dalam pembelajaran ekonomi pada materi ekonomi mikro dan makro yang menggunakan metode ceramah dan diskusi kelompok saat pembelajaran berlangsung didata oleh seorang observer melalui pembelajaran menggunakan metode ceramah dan diskusi kelompok pada materi ekonomi mikro dan makro di kelas X-7 SMANegeri 1 Katingan Hilir aktivitas guru dan peserta didik menunjukan perkembangan yang baik. Aktivitas guru dan peserta didik pada siklus I oleh pengamat memperoleh nilai ratarata 3,07 dan 3. Sedangkan pada siklus II ada peningkatan menjadi lebih baik, dengan penilaian ratarata oleh pengamat sebesar 3,71 dan 3,55.

2. Hasil belajar peserta didik

Hasil belajar peserta didik diperoleh dari data hasil tes awal nilai rata-rata peserta didik yang hanya memperoleh nilai rata-rata 40,41 nilai ini masih jauh dari kriteria ketuntasan minimal yang ditentukan yaitu 70. Hasil katuntasan belajar secara klasikal juga hanya memperoleh $21 \%$, sedangkan kriteria ketuntasan klasikal minimal $85 \%$.

Melalui pembelajaran menggunakan metode ceramah dan diskusi kelompok pada siklus I nilai rata-rata peserta didik mengalami peningkatan sebesar 61,25 meskipun belum mencapai kriteria ketuntasan minimal, secara klasikal pun belum mencapai $85 \%$ karena nilai yang diperoleh pada siklus I hanya sebesar 50\%. Pada siklus II nilai rata-rata peserta didik mengalami peningkatan cukup bagus dengan perolehan nilai rata-rata 80 dengan kriteria ketuntasan klasikal sebesar 87,5\%. Peneliti menganggap pada siklus II ini sudah berhasil karena telah mencapai nilai ketuntasan secara klasikal.

\section{KESIMPULAN}

Aktivitas peserta didik selama proses pembelajaran ekonomi menggunakan metode ceramah dan diskusi kelompok lebih terlihat aktif dan tidak terlihat monoton. Hal tersebut sesuai dengan yang diharapkan peneliti dan sesuai dengan data observasi yaitu pada siklus I memperoleh skor rata-rata 3,0 dengan kriteria baik yang dimana pada siklus II menjadi lebih baik lagi dan meningkat dengan skor rata-rata 3,7 dengan kriteria baik. Berdasarkan hasil tersebut dapat disimpulkan bahwa peserta didik merespon dan berperan terhadap kegiatan pembelajaran yang dilakukan dengan menggunakan metode ceramah dan diskusi kelompok.

Ada peningkatan bahwa hasil belajar ekonomi dengan menggunakan metode ceramah dan diskusi kelompok pada peserta didik kelas X-7 
SMAN 1 Katingan Hilir. Pada siklus I ada peningkatan hasil belajar peserta didik memperoleh data presentase $50 \%, 4$ orang peserta didik memperoleh nilai setara KKM, 12 orang peserta didik yang memperoleh nilai $>60$, sedangkan sisanya 8 orang peserta didik yang mendapat nilai $<60$ dari 24 peserta didik yang ada.

Kemudian adanya peningkatan pada siklus II dengan rata-rata skor presentase $87,5 \%$ dengan kriteria baik dimana dari 24 oarang peserta didik ada 16 orang yang mendapat nilai diatas KKM dan sisanya ada 8 orang peserta didik yang mendapat nilai >60 sehingga pada siklus II dinyatakan tuntas dari klasikal yang diharapkan.

\section{DAFTAR PUSTAKA}

Dimyati dan Mudjiono. (2006). Belajar dan Pembelajaran. Jakarta: Rineka Cipta.

Djamarah. 2008. Strategi Belajar Mengajar. Jakarta: Rineka Cipta.

Hamalik, Omar. 2005. Proses Belajar Mengajar, Jakarta: Dian Rakyat.

Killen. 2007. Perencanaan Pembelajaran. Bandung: Bumi Aksara

Kunandar. (2008). Penelitian Tindakan Kelas. Jakarta: PT. Raja Grafmdo Persada.

Sabri, A. 2007. Strategi Belajar Mengajar Micro teaching. Jakarta: Quantum Teaching. Bandung: QuantumTeaching.

Sudjana, Nana. 2007. Model-Model Mengajar CBSA. Bandung: Sinar Baru. 